\title{
Manganous ions suppress photosynthesis gene expression in Rhodobacter sphaeroides
}

\author{
Irene M. Horne, John M. Pemberton and Alastair G. McEwan \\ Author for correspondence: Alastair G. McEwan. Tel: +61 73365 4878. Fax: +61733654620. \\ e-mail: mcewan@biosci.uq.edu.au
}

Department of Microbiology, The

University of Queensland, Brisbane 4072, Australia

\begin{abstract}
The effect of manganous ions [Mn(II)] and ferrous ions [Fe(II)] on expression of photosynthesis genes in Rhodobacter sphaeroides was investigated. The presence of $\mathrm{Mn}$ (II) during phototrophic (anaerobic) and chemotrophic (aerobic) growth of $R$. sphaeroides caused a decrease in the amount of bacteriochlorophyll and carotenoid pigments which were synthesized and this was associated mainly with a decrease in the level of light-harvesting complex II. Mn(II) was shown to cause a decrease in expression of the puc operon, which encodes the polypeptides of light-harvesting complex II. Expression of the puc operon is controlled by the central repressor of photosynthesis gene expression, PpsR. In a ppsR mutant there was no effect of Mn(II) on photosynthesis gene expression. It is concluded that Mn(II) may act as a corepressor in the action of PpsR or act via an as yet uncharacterized protein that interacts with PpsR. In contrast to the effects of Mn(II), Fe(II) was required for high levels of photosynthesis gene expression. This requirement for Fe(II) was shown to be related to the regulation of hemA, a gene under the control of the transcriptional regulator, FnrL. Mn(II) did not affect FnrL-dependent gene expression.
\end{abstract}

Keywords: photosynthesis, gene expression, Rhodobacter sphaeroides, repressor PpsR, manganous ion

\section{INTRODUCTION}

Most species of purple non-sulfur phototrophic bacteria are facultative aerobes. They are able to grow chemoheterotrophically using oxygen as a terminal electron acceptor, and under anaerobic conditions in the light they can catalyse cyclic photosynthetic electron transfer during phototrophic growth (McEwan, 1994). Two environmental signals control the synthesis of the photosynthetic apparatus: oxygen represses its formation while under anaerobic conditions the size of the photosynthetic apparatus is inversely related to the incident light intensity (Aagaard \& Sistrom, 1972). The photosynthetic apparatus of Rhodobacter sphaeroides and Rhodobacter capsulatus contains three distinct pigment-protein complexes involved in the transduction of light energy into electrochemical energy (Kiley \& Kaplan, 1988). Two types of light-harvesting (LH) complex, LHI (or B875) and LHII (or B800-850), are identified by the distinctive absorbance maxima of their

Abbreviations: Bch, bacteriochlorophyll a; LHI, LHII, light-harvesting complex I, II; PS, photosynthesis. bacteriochlorophyll $a(\mathrm{Bch})$ pigments. The core of the photosynthetic unit consists of a reaction centre ( $\mathrm{RC}$ ) surrounded by $10-15$ LHI. The peripheral LHII complex surrounds the $\mathrm{LHI} / \mathrm{RC}$ core and its level is more variable with light intensity.

A number of the regulators of photosynthesis (PS) gene expression have now been identified, although their mechanism of oxygen and/or light sensing is still unclear. The oxygen-responsive transcriptional regulator FnrL has been identified as an activator of PS gene expression in R. sphaeroides (Zeilstra-Ryalls \& Kaplan, 1995) while the sensor histidine kinase-response regulator system PrrB-PrrA is also essential for activation of PS gene expression in response to a decrease in oxygen tension (Eraso \& Kaplan, 1994, 1995). Another key regulatory gene has been identified within the PS gene cluster. ppsR (formerly known as $c r t J$ ) encodes a repressor which shuts down PS gene expression in response to the presence of oxygen (Penfold \& Pemberton 1991, 1994). A ppsR mutant of $R$. sphaeroides was shown to synthesize high levels of $\mathrm{LH}$ complexes under aerobic conditions and this led to the view that PpsR must be a repressor of the transcription 
Table 1. Bacterial strains and plasmids used in this study

\begin{tabular}{|c|c|c|}
\hline Strain or plasmid & Relevant characteristics & Source or reference \\
\hline \multicolumn{3}{|l|}{ R. sphaeroides } \\
\hline RS630 & Wild-type & Pemberton \& Bowen (1981) \\
\hline PPSR & $\mathrm{RS} 630(p p s R), \mathrm{Kn}^{\mathrm{r}}$ & Penfold \& Pemberton (1994) \\
\hline \multicolumn{3}{|l|}{ E. coli } \\
\hline DH5 $\alpha$ & 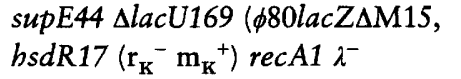 & Bethesda Research Labs \\
\hline S17-1 & $\begin{array}{l}\text { MM294 with RP4-2 (tet:: } \mathrm{Mu}, \\
\text { neo:: } \mathrm{Tn} 7 \text { ) integrated into the } \\
\text { chromosome, } \mathrm{Tra}^{+} \mathrm{Sm}^{\mathrm{r}} \mathrm{Tp}^{\mathrm{r}}\end{array}$ & Simon et al. (1983) \\
\hline \multicolumn{3}{|l|}{ Plasmids } \\
\hline pCF200 & 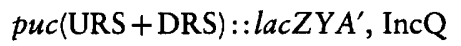 & Lee \& Kaplan (1992) \\
\hline pUI1063 & bemA::lacZYA', IncQ & Zeilstra-Ryalls \& Kaplan (1995) \\
\hline pUI1830 & $p u f B:: \operatorname{lac} Z Y A^{\prime}, \operatorname{lnc} Q$ & Gomelsky \& Kaplan (1995a) \\
\hline
\end{tabular}

of PS genes. It has been confirmed that PpsR represses the expression of a number of $c r t$ and $b c h$ genes (Penfold \& Pemberton, 1994; Gomelsky \& Kaplan, 1995a) and a consensus DNA sequence for the binding of PpsR has been identified (Gomelsky \& Kaplan, 1995a). Similar results for the PpsR homologue in $R$. capsulatus, still known as CrtJ, have been obtained by Bauer and co-workers and the ability of this protein to bind to its DNA target has been confirmed (Ponnampalam et al., 1995; Ponnampalam \& Bauer, 1997). PpsR can repress the expression of $R$. sphaeroides bch and $c r t$ genes in the heterologous hosts Paracoccus denitrificans and Pseudomonas stutzeri (Penfold \& Pemberton, 1994; Gomeisky \& Kaplan, 1995a), and this has led to the suggestion that PpsR may sense oxygen or an oxygeninduced metabolite directly.

Changes in metal concentration have been shown to affect the levels of pigments in $R$. sphaeroides. Lascelles and coworkers have extensively studied the affects of iron on pigment levels, porphyrin excretion and 5aminolaevulinic acid synthase activity (Burnham \& Lascelles, 1963; Lascelles, 1959). Iron-dependent regulators of gene expression have been identified in a variety of organisms; examples include the Fur protein (Hickey \& Ciancotto, 1994; Staggs \& Perry, 1992; Ernst et al., 1978) and the diphtheria toxin repressor (DtxR) of Corynebacterium diphtheriae (Boyd et al., 1990). In addition to proteins which may reversibly bind iron, there are other regulatory proteins which contain iron-sulfur clusters (Roualt \& Klausner, 1996). Perhaps the best-known example of this class of proteins is the transcriptional regulator Fnr, which, in Escherichia coli, has been shown to be regulated by iron availability (Trageser \& Unden, 1989). The presence of FnrL in $R$. sphaeroides (Zeilstra-Ryalls \& Kaplan, 1995) suggests that the iron-dependent stimulation of PS gene expression may involve this protein. The possibility that other metal ions have a role in the control in PS gene expression has not been explored in recent years. In this paper we describe experiments to determine whether $\mathrm{Mn}$ (II) ions affected PS gene expression.

\section{METHODS}

Bacterial strains, plasmids, media and growth conditions. The bacterial strains and plasmids used are listed in Table 1. RCV medium was routinely used for the cultivation of $R$. sphaeroides strains (Weaver et al., 1975). For 'Mn-free' RCV, $\mathrm{MnSO}_{4}$ was omitted and $\mathrm{Mn}(\mathrm{II})$ added from a sterile stock $\mathrm{MnSO}_{4}$ solution to the required concentration. This medium contained $24 \mu \mathrm{g} \mathrm{FeSO}_{4} .7 \mathrm{H}_{2} \mathrm{O} \mathrm{ml} \mathrm{m}^{-1}$. 'Fe-free' medium was prepared by omitting $\mathrm{FeSO}_{4} \cdot 7 \mathrm{H}_{2} \mathrm{O}$ from the RCV medium, and $\mathrm{Fe}$ was added to the appropriate concentration from a freshly prepared filter-sterilized solution of $\mathrm{FeSO}_{4} \cdot 7 \mathrm{H}_{2} \mathrm{O}$. This medium contained $1.6 \mu \mathrm{gnSO}_{4} \mathrm{ml}^{-1}$. $\mathrm{Ni}(\mathrm{II})$ was added to $\mathrm{RCV}$ from a sterile stock solution of $\mathrm{NiCl}_{2}$. All E. coli strains were grown on LB medium (Sambrook et al., 1989).

E. coli strains were grown at $37^{\circ} \mathrm{C}$ in $25 \mathrm{ml}$ liquid in $250 \mathrm{ml}$ flasks. $R$. sphaeroides strains were inoculated as previously described (Horne et al., 1996) in completely filled $30 \mathrm{ml}$ McCartney bottles and incubated at a light intensity of approximately $200 \mathrm{~W} \mathrm{~m}^{-2}$ calculated by the method of Clayton (1970). Antibiotics were added to the following final concentrations: tetracycline $10 \mu \mathrm{g} \mathrm{m}^{-1}$ (E. coli), spectinomycin $25 \mu \mathrm{g} \mathrm{ml}^{-1}$ (E. coli and R. sphaeroides), and kanamycin $25 \mu \mathrm{g}$ $\mathrm{ml}^{-1}$ (R. sphaeroides).

Spectroscopic, protein and enzyme analyses. Membranes for analysis of $\mathrm{LH}$ complexes were prepared from $R$. sphaeroides cell cultures as described previously (Horne et al., 1996). The level of $\mathrm{Bch}$ in the $\mathrm{LH}$ complexes was determined by the method of Meinhardt et al. (1984). The LH concentration was calculated assuming $2 \mathrm{~mol} \mathrm{Bch}$ per mol LHI and $3 \mathrm{~mol} \mathrm{Bch}$ per mol LHII. $\beta$-Galactosidase assays were performed according to the method of Clark \& Switzer (1977). Protein was determined using the bicinchoninic acid reagent with bovine serum albumin as a standard (Smith et al., 1985). All data are the means of at least two independent analyses and errors did not exceed $15 \%$.

Genetic manipulations. E. coli S17-1 (Simon et al., 1983) was used to transfer plasmids into $R$. sphaeroides strains. The 
mating method of Bonnett et al. (1995) was used for conjugal transfer. Molecular biological enzymes and reagents were used according to the specifications of the manufacturers.

\section{RESULTS}

Effect of Mn(II) on the level of LH complexes in $R$. sphaeroides RS630

Kassner \& Kamen (1968) observed that the level of Bch pigment in phototrophically grown $R$. sphaeroides was lowered when $\mathrm{Mn}$ (II) ions were supplied in the growth medium. This result was confirmed in our experiments and a more detailed analysis was performed. Fig. 1 shows the spectra of membranes from $R$. sphaeroides grown phototrophically at $200 \mathrm{~W} \mathrm{~m}^{-2}$ in the presence of $\mathrm{Mn}\left(\mathrm{II}\right.$ ) (at a final concentration of $100 \mu \mathrm{g} \mathrm{MnSO}_{4} \mathrm{ml}^{-1}$ ) and in the absence of added $\mathrm{Mn}$ (II). Absorption due to Bch in the LHII complex can be seen as a peak at $800 \mathrm{~nm}$ and at $850 \mathrm{~nm}$ while the Bch in LHI can be seen as a shoulder on the absorption peak at $850 \mathrm{~nm}$. The presence of $\mathrm{Mn}$ (II) in the growth medium caused a decrease in the level of Bch pigments in LHII and LHI under phototrophic (anaerobic) conditions (Fig. 1). The absorption peaks between $450 \mathrm{~nm}$ and $550 \mathrm{~nm}$ correspond to Crt pigments. The presence of $\mathrm{Mn}$ (II) in the growth medium also caused a lowering in the level of Crt pigments (Fig. 1). This is taken to indicate that $\mathrm{Mn}$ (II) ions were affecting the level of LH complexes and not their composition.

Table 2 shows the level of $\mathrm{LH}$ complexes in membranes from $R$. sphaeroides grown phototrophically and aerobically as a function of the $\mathrm{Mn}$ (II) concentration in the growth medium. In phototrophically grown cells the presence of $100 \mu \mathrm{g} \mathrm{MnSO}_{4} \mathrm{ml}^{-1}$ caused the level of LHI to be $20 \%$ lower than its level in cells grown without added $\mathrm{Mn}$ (II). The decrease in LHII caused by the

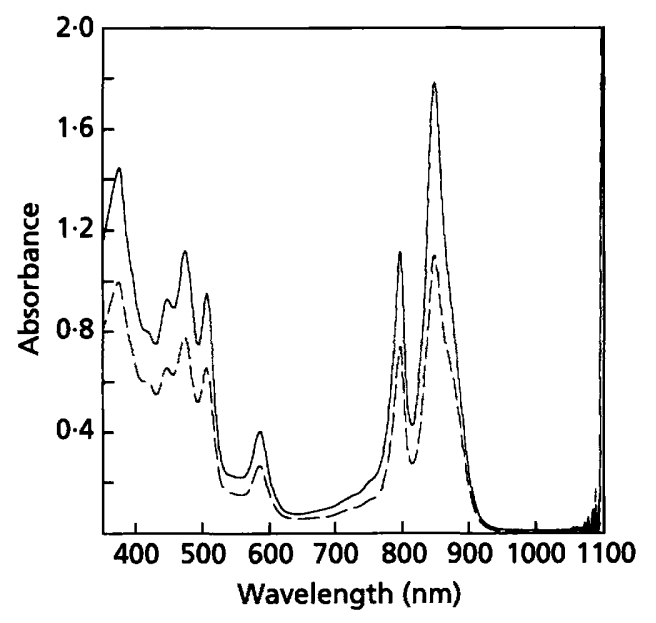

Fig. 1. Absorption spectra of membranes of $R$. sphaeroides strain RS630 grown phototrophically in the absence (solid line) and presence (dashed line) of $100 \mu \mathrm{g} \mathrm{MnSO}_{4} \mathrm{ml}^{-1}$ in RCV medium. Both samples contained $195 \mu \mathrm{g}$ protein.
Table 2. Level of light-harvesting complexes in membranes from $R$. sphaeroides RS630 grown at various $\mathrm{Mn}(\mathrm{II})$ ion concentrations

\begin{tabular}{|c|c|c|c|c|}
\hline \multirow{3}{*}{$\begin{array}{l}\text { Growth } \\
\text { conditions* }\end{array}$} & \multicolumn{4}{|c|}{ LH level [nmol (mg protein $\left.)^{-1}\right]$} \\
\hline & \multicolumn{4}{|c|}{$\mathrm{MnSO}_{4}$ concn $\left(\mu \mathrm{g} \mathrm{ml}^{-1}\right):$} \\
\hline & $\mathbf{0}$ & 1 & 10 & 100 \\
\hline \multicolumn{5}{|l|}{ PS } \\
\hline LHI & $15 \cdot 0$ & $14 \cdot 2$ & $13 \cdot 3$ & $12 \cdot 0$ \\
\hline LHII & $23 \cdot 8$ & $18 \cdot 3$ & $17 \cdot 4$ & $14 \cdot 7$ \\
\hline \multicolumn{5}{|l|}{$\mathrm{O}_{2}$} \\
\hline LHI & $1 \cdot 65$ & $1 \cdot 35$ & $1 \cdot 0$ & 0.97 \\
\hline LHII & $0 \cdot 83$ & 0.62 & $0 \cdot 4$ & $0 \cdot 36$ \\
\hline
\end{tabular}

*PS, phototrophic conditions; $\mathrm{O}_{2}$, chemotrophic conditions.

presence of $\mathrm{Mn}(\mathrm{II})$ was even greater (38\%) (Table 2). $\mathrm{Mn}$ (II)-dependent suppression of LH levels was also observed in cells grown at lower light intensity $(16 \mathrm{~W}$ $\mathrm{m}^{-2}$ ) (data not shown). During chemoheterotrophic aerobic growth of $R$. sphaeroides there is strong repression of PS gene expression but the presence of $\mathrm{Mn}$ (II) also caused a decrease in the level of $\mathrm{LH}$ complexes under these conditions (Table 2). This showed that the effect of $\mathrm{Mn}(\mathrm{II})$ ions was not restricted to phototrophic conditions.

\section{Comparison of the effect of $\mathrm{Mn}(\mathrm{II}), \mathrm{Fe}$ (II) and $\mathrm{Ni}(\mathrm{II})$ ions on LH levels in R. sphaeroides}

Since $\mathrm{Mn}(\mathrm{II})$ affected the level of LH complexes in $R$. sphaeroides, the effect of other divalent cations from the first transition series was examined. Fe(II) was chosen because in some proteins it has been shown that $\mathrm{Mn}$ (II) can substitute for $\mathrm{Fe}(\mathrm{II})$ (Hantke, 1987; Trageser \& Unden, 1989). The effect of $\mathrm{Fe}(\mathrm{II})$ concentration on the level of LH complexes in $R$. sphaeroides grown phototrophically is shown in Fig. 2. There was an increase in the level of both LHI and LHII as the Fe(II) concentration in the growth medium increased. In this medium, $\mathrm{Mn}$ (II) was at a constant concentration of $1.6 \mu \mathrm{g} \mathrm{MnSO}_{4} \mathrm{ml}^{-1}$. The effect of $\mathrm{Fe}$ (II) concentration on the level of $\mathrm{LH}$ complexes was opposite to the effect of $\mathrm{Mn}$ (II). Fig. 2 also shows that low levels of $\mathrm{Mn}$ (II) exert a dramatic effect on the level of LH complexes. The growth medium used for the titration with $\mathrm{Mn}$ (II) ions contained $24 \mu \mathrm{g} \mathrm{FeSO} \mathrm{O}_{4} \cdot 7 \mathrm{H}_{2} \mathrm{O} \mathrm{ml} \mathrm{m}^{-1}$ and this suggested that $\mathrm{Mn}(\mathrm{II})$ exerted its effect on the formation of $\mathrm{LH}$ complexes independently of $\mathrm{Fe}$ (II). The level of $\mathrm{LH}$ complexes did not change significantly as a function of $\mathrm{Ni}$ (II) concentration except at high concentrations $\left(100 \mu \mathrm{g} \mathrm{ml}^{-1}\right)$ of this ion (data not shown). This can be attributed to toxic effects of $\mathrm{Ni}(\mathrm{II})$ because it caused the growth rate of $R$. sphaeroides to decrease. In contrast, $\mathrm{Mn}(\mathrm{II})$ at $100 \mu \mathrm{g} \mathrm{ml}^{-1}$ in the medium had no effect on the growth rate of $R$. sphaeroides under the experimental conditions used. 


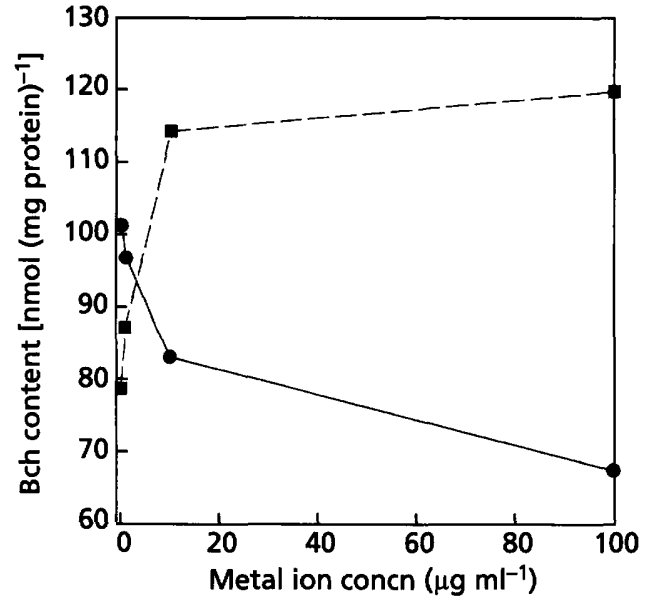

Fig. 2. Effect of $\mathrm{Mn}$ (II) (O) and $\mathrm{Fe}(\mathrm{II})(\square)$ concentration on the Bch content of membranes from $R$. sphaeroides strain RS630 grown phototrophically in RCV medium. The concentrations plotted are those of the respective sulfate.

\section{Effect of $\mathrm{Mn}$ (II) and Fe(II) ions on PS gene expression}

FnrL has been identified as a key regulator of PS gene expression in $R$. sphaeroides by virtue of its role as an activator of the expression of the bemA gene (ZeilstraRyalls \& Kaplan, 1995). The bemA gene encodes an isozyme of 5-aminolaevulinic acid synthase, the first step in Bch synthesis. Fnr is known to contain an [Fe-S] cluster (Lazazzara et al., 1996) and Fe(II) ions have been shown to affect Fnr-dependent gene expression in E. coli (Niehaus et al., 1991). Mn(II) has also been suggested to be capable of affecting the Fnr-dependent regulation of gene expression (Trageser \& Unden, 1989). Therefore we examined the effect of $\mathrm{Mn}$ (II) and $\mathrm{Fe}$ (II) ions on the expression of an hemA-lacZ transcriptional fusion. Table 3 shows the $\beta$-galactosidase activity, corresponding to the degree of expression from the hemA promoter, in cell-free extracts from $R$. sphaeroides grown phototrophically. The expression of hemA did not appear to change as a function of $\mathrm{Mn}$ (II) concentration but, as expected for an Fnr-regulated gene, hem $A$ expression increased with the concentration of $\mathrm{Fe}$ (II) ions in the medium. These data supported the view that the effect of $\mathrm{Mn}$ (II) ions on PS gene expression is not exerted via FnrL.

Regulation of the formation of the photosynthetic apparatus occurs at the level of transcription as well as at the post-transcriptional and post-translational level (Kiley \& Kaplan, 1988). To determine whether the effect of $\mathrm{Mn}$ (II) ions on LH complex formation was mediated at the level of transcription, the expression of $p u f-l a c Z$ and $p u c-l a c Z$ gene fusions was examined in $R$. sphaeroides RS630 grown phototrophically in the presence and absence of $\mathrm{Mn}(\mathrm{II})$. The puf operon encodes the structural polypeptides of LHI and two polypeptides of the photochemical reaction centre, and the puc operon includes genes encoding the structural polypeptides of LHII (Kiley \& Kaplan, 1988). The $\beta$-galactosidase activity in cell-free extracts from strains expressing these gene fusions is shown in Table 3 . A $28 \%$ reduction in puc expression was observed in R. sphaeroides grown in the presence of $100 \mu \mathrm{g} \mathrm{Mn}$ (II) $\mathrm{ml}^{-1}$ compared to cells grown in the absence of this ion. In contrast there was no significant effect of $\mathrm{Mn}$ (II) concentration on the level of puf expression (Table 3).

\section{Effect of $\mathrm{Mn}$ (II) and $\mathrm{Fe}$ (II) concentration on LH complex levels and PS gene expression in a ppsR mutant}

The $p p s R$ gene encodes a repressor of the expression of the puc operon and a number of $b c h$ genes (Penfold $\&$ Pemberton, 1994; Gomelsky \& Kaplan, 1995a). The effect of $p p s R$ on PS gene expression is most obvious under aerobic conditions; the presence of $p p s R$ in multicopy causes suppression of LH complex formation (Penfold \& Pemberton, 1991) whilst a $p p s R$ mutant fails to repress PS gene expression in response to the presence of oxygen (Penfold \& Pemberton, 1994). However, it has been shown that a $p p s R$ mutant of $R$. sphaeroides synthesizes higher levels of $\mathrm{LH}$ complexes compared to wild-type cells under phototrophic conditions and this indicates that PpsR is active in the absence of oxygen (Gomelsky \& Kaplan, 1997). The role of $\mathrm{Mn}(\mathrm{II})$ and $\mathrm{Fe}(\mathrm{II})$ in PpsR-dependent regulation of PS gene expression was investigated in $R$. sphaeroides grown

Table 3. $\beta$-Galactosidase activity in cell extracts of $R$. sphaeroides RS630 bearing lacZ transcriptional fusions grown phototrophically with various metal ions

\begin{tabular}{|c|c|c|c|c|}
\hline \multirow[t]{3}{*}{ lac $Z$ fusion } & \multicolumn{4}{|c|}{$\beta$-Galactosidase activity [nmol ONPG hydrolysed $\left.\min ^{-1}(\text { mg protein })^{-1}\right]$} \\
\hline & \multicolumn{2}{|c|}{$\mathrm{MnSO}_{4}$ concn $\left(\mu \mathrm{g} \mathrm{ml}^{-1}\right)$} & \multicolumn{2}{|c|}{$\mathrm{FeSO}_{4}$ concn $\left(\mu \mathrm{g} \mathrm{ml}^{-1}\right)$} \\
\hline & 0 & 100 & 0 & 100 \\
\hline$p u c$ & 5300 & 3800 & ND & ND \\
\hline puf & 5700 & 5200 & ND & ND \\
\hline hem $A$ & 1500 & 1500 & 500 & 1100 \\
\hline
\end{tabular}

ND, Not determined. 
Table 4. Level of LH complexes and puc expression in $R$. sphaeroides PPSR grown under phototrophic conditions with various concentrations of $\mathrm{Fe}$ (II) ions and $\mathrm{Mn}$ (II) ions

\begin{tabular}{|lccc|}
\hline $\begin{array}{l}\text { Metal ion concn } \\
\text { ( } \mu \mathrm{m} \mathrm{m}^{-1} \text { of sulfate) }\end{array}$ & LH complex level [nmol (mg protein) ${ }^{-1}$ ] & $\begin{array}{c}\beta \text {-Galactosidase } \\
\text { activity [nmol ONPG } \\
\text { hydrolysed } \text { min }^{-1} \\
\left.\text { (mg protein) }^{-1}\right]^{*}\end{array}$ \\
\hline $\mathrm{MnSO}_{4}$ & LHI & LHII & \\
0 & $18 \cdot 9$ & $26 \cdot 3$ & 7800 \\
100 & $18 \cdot 2$ & $24 \cdot 6$ & 7500 \\
$\mathrm{FeSO}_{4}$ & & & \\
0 & $11 \cdot 0$ & $16 \cdot 6$ & ND \\
100 & $16 \cdot 3$ & $26 \cdot 3$ & ND \\
\hline
\end{tabular}

*Expression of a puc-lacZ fusion. ND, Not determined.

phototrophically. Table 4 shows that the level of $\mathrm{LH}$ complexes in the $p p s R$ mutant $R$. sphaeroides PPSR was higher than that of $R$. sphaeroides RS630 under these conditions (compare Table 2). However, the level of LH complexes in the $p p s R$ mutant did not appear to alter in response to increased $\mathrm{Mn}$ (II) concentration, in contrast to the $\mathrm{Mn}$ (II)-dependent suppression of $\mathrm{LH}$ complex formation observed with the wild-type. Table 4 also shows that the level of LH complexes increased with increasing $\mathrm{Fe}(\mathrm{II})$ concentration in PPSR as it did in RS630. Since puc-lacZ expression was affected by $\mathrm{Mn}$ (II) concentration in strain RS630 (Table 3) the effect of $\mathrm{Mn}$ (II) concentration on the activity of this gene fusion in the $p p s R$ mutant was examined. The expression of $p u c-l a c Z$ was independent of $\mathrm{Mn}$ (II) concentration in strain PPSR (Table 4). These data are consistent with the view that the effect of $\mathrm{Fe}$ (II) concentration on LH complex formation is independent of PpsR but suggest that $\mathrm{Mn}$ (II) might exert its effect via this repressor.

\section{DISCUSSION}

The role of transition metals, particularly iron, in the regulation of gene expression is well documented (Hennecke, 1990). PS gene expression is no exception and it is established that one activator of PS gene expression is the [Fe-S] protein FnrL (Zeilstra-Ryalls \& Kaplan, 1995). An area of cell physiology where iron has particular importance is in the regulation of gene expression in response to oxygen. In the case of Fnr it has been suggested that regulation by oxygen may involve oxygen-dependent destruction of the [Fe-S] cluster (Beinert \& Kiley, 1996). Iron can exist in the $\mathrm{Fe}(\mathrm{II})$ and $\mathrm{Fe}(\mathrm{III})$ states and this raises the possibility that changes in the redox state of iron might also be important in the regulation of metabolism and gene expression (Williams, 1982; Unden et al., 1995). The requirement for iron in haemoproteins and [Fe-S] proteins means that iron-limitation often restricts bacterial cell growth and gene expression, and this is the case for PS gene expression. The effect of $\mathrm{Fe}$ (II) limitation on the level of $\mathrm{LH}$ complexes can be explained as arising from a restriction in the synthesis of key [Fe-S] proteins. FnrL is a positive regulator of hemA and puc expression (Zeilstra-Ryalls \& Kaplan, 1995) while BchX is an [Fe-S] protein which is involved in a key step in Bch synthesis (Burke et al., 1993). Fnr-dependent gene expression in $E$. coli has been shown to be affected by changes in $\mathrm{Fe}$ (II) concentration (Niehaus et al., 1991; Trageser \& Unden, 1989) and the situation appears to be similar for the FnrL-dependent expression of hemA expression in R. sphaeroides (this work). Experiments with permeabilized $E$. coli cells have suggested that Mn(II) might affect Fnr (Trageser \& Unden, 1989) but there is no indication that $\mathrm{Mn}$ (II) concentration affects the FnrL in $R$. sphaeroides. $\mathrm{Mn}$ (II) can substitute for $\mathrm{Fe}$ (II) as an activating ion for the Fur protein (Hantke, 1987). However, the concentrations of $\mathrm{Mn}$ (II) which are required are in a huge excess over the levels used in the experiments described in this paper and this leads us to conclude that the effect of Mn(II) on PS gene expression is not due to its ability to partially substitute for $\mathrm{Fe}$ (II).

The observation that $\mathrm{Mn}$ (II) had no effect on PS gene expression or LH complex levels in a $p p s R$ mutant leads to the possibility that $\mathrm{Mn}$ (II) is a co-repressor of the PpsR repressor system of $R$. sphaeroides. The observation that $\mathrm{Mn}(\mathrm{II})$ affected the expression of the $p u c$ operon but not the puf operon is consistent with this view since only the former has a consensus binding sequence for PpsR (Gomelsky \& Kaplan, 1995a). The lowering of puf-lacZ expression in response to an increase of $\mathrm{Mn}$ (II) concentration probably reflects the coupling of puf expression to Bch production; the expression of a number of operons encoding enzymes of Bch biosynthesis is repressed by PpsR (Gomelsky \& Kaplan, 1995a, 1997). PpsR was first identified as a repressor of PS gene expression which operated under aerobic conditions (Penfold \& Pemberton, 1991, 1994) but it now appears that PpsR can operate under anaerobic conditions (Gomelsky \& Kaplan, 1997; this work). Recently, Ponnampalam \& Bauer (1997) have presented evidence that the PpsR homologue in $R$. capsulatus is a redox sensor, although no mechanism of action was obvious. Inspection of the amino acid 
sequence of PpsR reveals that it possesses only two cysteine residues and one of these (Cys424) lies in the DNA-binding motif (Penfold \& Pemberton, 1994); it seems highly unlikely that PpsR would contain an $[\mathrm{Fe}-\mathrm{S}]$ cluster as a sensory component. If $\mathrm{Mn}$ (II) were bound to PpsR, it would most likely involve amino acid residues with $\mathrm{N}$ and $\mathrm{O}$ side chains and not a cysteine residue. This is because sulfur donors would be overwhelmingly occupied by $\mathrm{Fe}(\mathrm{II}), \mathrm{Cu}$ (II) or $\mathrm{Zn}$ (II) as predicted by the Irving-Williams series of divalent cation-ligand stability constants (Williams, 1982). A possible role for $\mathrm{Mn}$ (II) in PpsR could be to stabilize the oxidized form of PpsR, thereby enhancing the repression of PS gene expression. However, there is no direct evidence for this model at present. Indeed, CrtJ, the PpsR homologue in $R$. capsulatus, was shown not to contain metals as part of the protein (Ponnampalam \& Bauer, 1997). However, $\mathrm{Mn}$ (II) can often be lost from proteins during purification and so the question of whether PpsR contains metal ions should be approached with caution.

Since there is no direct evidence that $\mathrm{Mn}$ (II) is a component of PpsR, then it is also possible that $\mathrm{Mn}$ (II) influences the activity or expression of proteins which interact with PpsR. Genetic experiments have indicated that a protein AppA may positively regulate PS gene expression by antagonizing the action of the repressor PpsR (Gomelsky \& Kaplan, 1997). Furthermore, it seems likely that the Prr system may interact with PpsR because overexpression of the $a p p A$ gene can suppress the pigmentless phenotype of a PrrA mutant (Gomelsky \& Kaplan, 1995b).

It has recently been shown in Bacillus subtilis that low levels of $\mathrm{Mn}$ (II) inhibit the production of MrgA, a Dps homologue involved in protection of DNA during oxidative stress (Chen et al., 1993, Chen \& Helmann, 1995). Further experiments have shown that $\mathrm{Mn}(\mathrm{II})$ suppresses the coordinate derepression of a number of genes involved in a peroxide stress response (Chen et al., 1995). These data have been interpreted as indicating the existence of a peroxide stress gene repressor which binds $\mathrm{Mn}(\mathrm{II})$ and senses hydrogen peroxide. Although putative operator sites have been identified in a number of $B$. subtilis peroxide stress genes (Chen et al., 1995) no trans-acting factor has yet been identified. Our results suggest that $\mathrm{Mn}$ (II)-dependent regulation of gene expression is not restricted to Gram-positive bacteria such as Bacillus.

\section{ACKNOWLEDGEMENTS}

I.M.H. was supported by an Australian Postgraduate Award. A. G. M and J.M.P thank the University of Queensland for an Enabling Research Grant. The authors thank Therese Del Dot for help with preliminary investigations.

\section{REFERENCES}

Aagaard, J. \& Sistrom, W. R. (1972). Control of synthesis of reaction center bacteriochlorophyll in Rhodopseudomonas sphaeroides. Photochem Photobiol 15, 209-225.
Beinert, H. \& Kiley, P. (1996). Redox control of gene expression involving iron-sulfur proteins. Change of oxidation-state or assembly/disassembly of Fe-S clusters? FEBS Lett 382, 218-219.

Bonnett, T. C., Cobine, P., Sockett, R. E. \& McEwan, A. G. (1995). Phenotypic characterization and genetic complementation of dimethylsulfoxide respiratory mutants of Rhodobacter sphaeroides and Rhodobacter capsulatus. FEMS Microbiol Lett 133, 163-168.

Boyd, J., Oza, M. N. \& Murphy, J. R. (1990). Molecular cloning and DNA sequence of a diphtheria to $x$ iron-dependent regulatory element (dtxR) from Corynebacterium diphtheriae. Proc Natl Acad Sci USA 87, 5968-5972.

Burke, D. H., Alberti, M. \& Hearst, J. E. (1993). The Rhodobacter capsulatus chlorin reductase-encoding locus, $b c h A$, consists of three genes, bchX, bchY and bchZ. J Bacteriol 175, 2407-2413.

Burnham, B. F. \& Lascelles, J. (1963). Control of porphyrin biosynthesis through a negative feedback mechanism. Biochem $J$ 87, 462-472.

Chen, L. \& Helmann, J. D. (1995). Bacillus subtilis MrgA is a Dps (PexB) homologue: evidence for metalloregulation of oxidativestress gene. Mol Microbiol 18, 295-300.

Chen, L., James, L. P. \& Helmann, J. D. (1993). Metalloregulation in Bacillus subtilis: isolation and characterization of two genes differentially repressed by metal ions. J Bacteriol 175, 5428-5437.

Chen, L., Keramati, L. \& Helmann, J. D. (1995). Coordinate regulation of Bacillus subtilis peroxide stress genes by hydrogen peroxide and metal ions. Proc Natl Acad Sci USA 92, 8190-8194.

Clark, J. M., Jr \& Switzer, R. L. (1977). Experimental Biochemistry, p. 97. New York: W. H. Freeman.

Clayton, R. K. (1970). Light and Living Matter, vol. 1, The Physical Part. New York: McGraw-Hill.

Eraso, J. M. \& Kaplan, S. (1994). prrA, a putative response regulator involved in oxygen regulation of photosynthesis gene expression in Rhodobacter sphaeroides. J Bacteriol 176, 32-43.

Eraso, J. M. \& Kaplan, S. (1995). Oxygen-insensitive synthesis of the photosynthetic membranes of Rhodobacter sphaeroides: a mutant histidine kinase. J Bacteriol 177, 2695-2706.

Ernst, J. F., Bennett, R. L. \& Rothfield, L. I. (1978). Constitutive expression of the iron-enterochelin and ferrichrome uptake systems in a mutant strain of Salmonella Typhimurium. J Bacteriol 135, 928-934.

Gomelsky, M. \& Kaplan, S. (1995a). Genetic evidence that PpsR from Rhodobacter sphaeroides 2.4 .1 functions as a repressor of puc and bchF expression. J Bacteriol 177, 1634-1637.

Gomelsky, M \& Kaplan, S. (1995b). appA, a novel gene encoding a trans-acting factor involved in the regulation of photosynthesis gene expression in Rhodobacter sphaeroides 2.4.1. J Bacteriol 172, 4609-4618.

Gomelsky, M. \& Kaplan, S. (1997). A molecular genetic analysis suggesting interactions between AppA and PpsR in the regulation of photosynthesis gene expression in Rhodobacter sphaeroides 2.4.1. J Bacteriol 179, 128-134.

Hantke, K. (1987). Selection procedure for deregulated iron transport mutants (fur) in Escherichia coli K12: fur not only affects iron metabolism. Mol Gen Genet 210, 135-139.

Hennecke, H. (1990). Regulation of bacterial gene expression by metal-protein complexes. Mol Microbiol 4, 1621-1628.

Hickey, E. K. \& Ciancotto, N. P. (1994). Cloning and sequencing of the Legionella pneumophila fur gene. Gene 143, 117-121.

Horne, I. M., Pemberton, J. M. \& McEwan, A. G. (1996). Photosynthesis gene expression in Rhodobacter sphaeroides is regulated 
by redox changes which are linked to electron transport. Microbiology 142, 2831-2838.

Kassner, R. J. \& Kamen, M. D. (1968). Trace metal composition of photosynthetic bacteria. Biochim Biophys Acta 153, 270-278.

Kiley, P. J. \& Kaplan, S. (1988). Molecular genetics of photosynthetic membrane biosynthesis in Rhodobacter sphaeroides. Microbiol Rev 52, 50-69.

Lascelles, J. (1959). Adaptation to form bacteriochlorophyll in $R$ hodopseudomonas sphaeroides: changes in activity of enzymes concerned in pyrrole synthesis. Biochem J 72, 508-518.

Lazazzera, B. A., Beinert, H., Khoroshilova, N., Kennedy, M. C. \& Kiley, P. J. (1996). DNA binding and dimerization of the Fe-Scontaining FNR protein from Escherichia coli are regulated by oxygen. J Biol Chem 271, 2762-2768.

Lee, J. K. \& Kaplan, S. (1992). cis-acting regulatory elements involved in oxygen regulation of puc operon transcription in Rhodobacter sphaeroides. J Bacteriol 174, 1158-1171.

McEwan, A. G. (1994). Photosynthetic electron transport and anaerobic metabolism in purple non-sulfur bacteria. Antonie Leeuwenhoek 66, 151-164.

Meinhardt, S. W., Kiley, P. J., Kaplan, S., Crofts, A. R. \& Harayama, S. (1984). Characterization of light-harvesting mutants of $R$ hodopseudomonas sphaeroides. I. Measurement of the efficiency of energy transfer from the light-harvesting complexes to the reaction centre. Arch Biochem Biophys 236, 130-139.

Niehaus, F., Hantke, K. \& Unden, G. (1991). Iron content and FNR-dependent gene regulation in Escherichia coli. FEMS Microbiol Lett 84, 319-324.

Pemberton, J. M. \& Bowen, A. R. St G. (1981). High frequency chromosome transfer in Rhodopseudomonas sphaeroides promoted by the broad host range plasmid RP1 carrying the mercury transposon Tn501. J Bacteriol 161, 469-472.

Penfold, R. J. \& Pemberton, J. M. (1991). A gene from the photosynthetic gene cluster of Rhodobacter sphaeroides induces trans suppression of bacteriochlorophyll and carotenoid levels in R. sphaeroides and R. capsulatus. Curr Microbiol 23, 259-263.

Penfold, R. J. \& Pemberton, J. M. (1994). Sequencing, chromosomal inactivation and functional expression in Escherichia coli of $p p s R$, a gene which represses carotenoid and bacteriochlorophyll synthesis in Rhodobacter sphaeroides. $J$ Bacteriol 176, 2869-2876.
Ponnampalam, S. N. \& Bauer, C. E. (1997). DNA binding characteristics of CrtJ. J Biol Chem 272, 18391-18396.

Ponnampalam, S. N., Buggy, J. J. \& Bauer, C. E. (1995). Purification and characterization of the aerobic repressor Crt J that coordinately regulates bacteriochlorophyll, carotenoid and lightharvesting II expression in Rhodobacter capsulatus. In Abstracts of the Diversity, Genetics and Physiology of Photosynthetic Prokaryotes, Indiana University Bloomington, Indiana, USA, abstract 37.

Rouault, T. A. \& Klausner, R. D. (1996). Iron-sulfur clusters as biosensors of oxidants and iron. Trends Biochem Sci 21, 174-177.

Sambrook, J., Fritsch, E. F. \& Maniatis, T. (1989). Molecular Cloning: a Laboratory Manual, 2nd edn. Cold Spring Harbor, NY: Cold Spring Harbor Laboratory.

Simon, R., Priefer, U. \& Puhler, A. (1983). A broad host range mobilization system for in vivo genetic engineering: transposon mutagenesis in Gram-negative bacteria. Bio/Technology 1, 784-791.

Smith, P. K., Krohn, R. I., Hermanson, G. T. \& 7 other authors (1985). Measurement of protein using bicinchoninic acid. Anal Biochem 150, 76-85.

Staggs, T. M. \& Perry, R. D. (1992). Fur regulation in Yersinia species. Mol Microbiol 6, 2507-2516.

Trageser, M. \& Unden, G. (1989). Role of cysteine residues and of metal ions in the regulatory functioning of FNR, the transcriptional regulator of anaerobic respiration in Escherichia coli. Mol Microbiol 3, 593-599.

Unden, G., Becker, S., Bongaerts, J., Holighaus, G., Schirawaski, J. \& Six, S. (1995). $\mathrm{O}_{2}$-sensing and $\mathrm{O}_{2}$-dependent gene regulation in facultatively anaerobic bacteria. Arch Microbiol 164, 81-90.

Weaver, P. F., Wall, J. D. \& Gest, H. (1975). Characterization of Rhodopseudomonas capsulata. Arch Microbiol 105, 207-216.

Williams, R. J. P. (1982). Free manganese (II) and iron (II) cations can act as intracellular cell controls. FEBS Lett 140, 3-10.

Zeilstra-Ryalls, J. H. \& Kaplan, S. (1995). Aerobic and anaerobic regulation in Rhodobacter sphaeroides 2.4.1: the role of the fnrL gene. J Bacteriol 177, 6422-6431.

Received 5 February 1998; revised 5 May 1998; accepted 12 May 1998. 